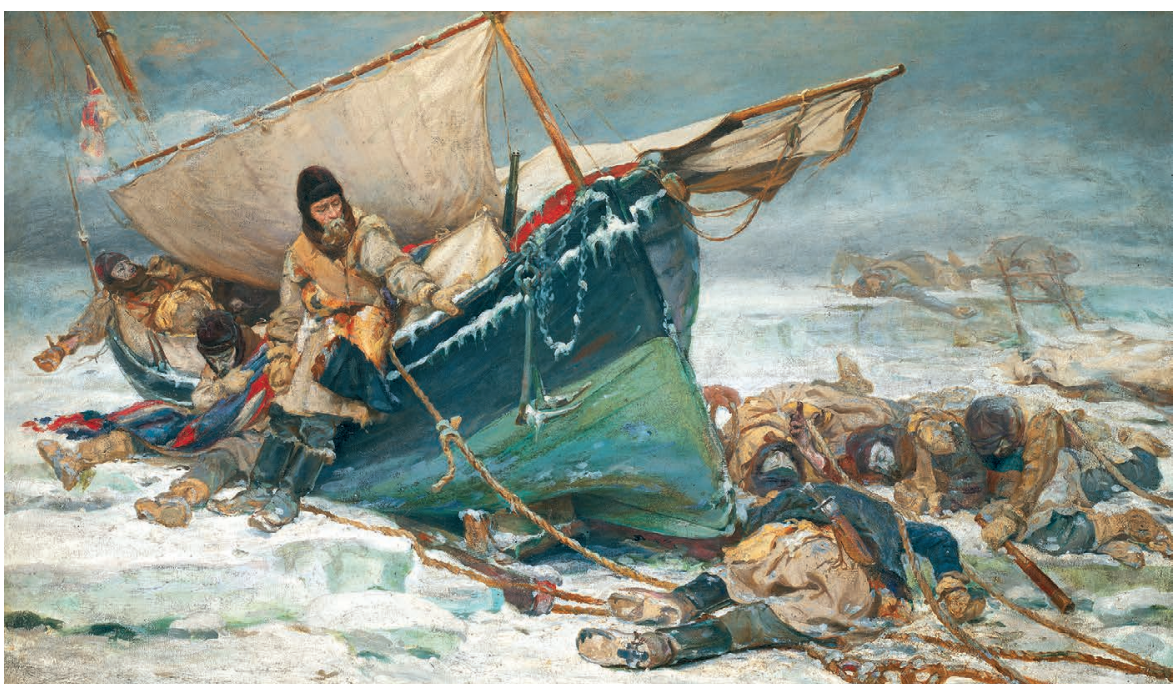

The last moments of John Franklin's Arctic expedition, imagined by William Thomas Smith in 1895.

\title{
Tracking down a doomed Arctic expedition
}

\section{Daniel Cressey surveys the remains of John Franklin's fatal 1845 voyage.}

“ $\mathrm{N}$ o one ever embarked on an expedition with more causes of rejoicing than ourselves." So wrote naval officer John Franklin before setting off from England in May 1845 to complete navigation of the North-West Passage through the Arctic reaches of North America. His bold declaration was soon to ring hollow.

Visitors to London's National Maritime Museum (NMM) this year can see the only written evidence of what happened to Franklin, his crew and their vessels, HMS Erebus and HMS Terror. Found in 1859 in a cairn on King William Island in the Canadian Arctic Archipelago, the note - dated 25 April 1848 - is scrawled around the edge of a log entry from the previous year. It describes the deaths of Franklin and 23 of his companions, the abandonment of their icebound ships, and survivors' plans to set out on foot.

They failed. All 129 members of the expedition vanished.

The note is one of more than 200 artefacts on show in Death in the Ice, an exhibition on the ill-fated voyage developed by the NMM and partners including the Canadian Museum of History $(\mathrm{CMH})$ in Gatineau (the exhibition will be on show at the CMH from 2 March to 30 September 2018). Exhibits range from humble eating utensils to the grand Royal Guelphic Order medal awarded to Franklin for his long service to the British Empire. Some of the objects were discovered by later expeditions looking for clues; there were 36 such hunts between 1847 and 1859 alone.

More remarkable are items recovered from the wrecked Erebus, discovered in 2014 (followed by Terror in 2016), preserved in the cold waters off the coast of Canada's Nunavut territory. Finds retrieved from Erebus are now on display for the first time, alongside a video of the sunken vessels.

The Franklin expedition was the largest Britain had sent to the Arctic. As senior NMM curator Claire Warrior says, "It was a matter of pride and prestige, of scientific research, of mapping and of projecting Royal Naval power." The expedition aimed to catalogue regional wildlife, geology and weather, as well as to fly the flag. The ships were strengthened to handle the harsh polar seas and provisioned, notes Warrior, with those British essentials "tea, chocolate and very strong rum".

After a while, the silence from Franklin $\begin{array}{ll}\text { recovered from John } & \text { and his crew became } \\ \text { Franklin's ship Erebus. "unnerving", Warrior }\end{array}$
Death in the Ice: The Shocking Story of Franklin's Final Expedition National Maritime Museum, London. 14 July 2017 7 January 2018. says. The missing expedition turned into a national obsession. Lurid reports of starving men, icy deaths and, shockingly, cannibalism began to trickle back to London from other explorers in the region. Literary lion Charles Dickens took issue with the idea of men of the British Navy resorting to such behaviour, asserting that the claim was based on the testimony of "covetous, treacherous, and cruel" indigenous people who might have done in the valiant tars themselves. Whatever the expedition's fate, it was clear - as Warrior relates - that a "surefire triumph had become tragedy".

The show probes several theories about the mass disappearance. One hint is a single shoe raised from Erebus: it looks like something you'd wear to the corner shop, not on a brutal voyage through freezing gales. One of Franklin's mittens, fashioned from wool and silk, looks equally conducive to frostbite. A 'forensic zone' unpicks evidence for other culprits. Did the crew succumb to lead poisoning from the solder that sealed their canned food? Perhaps it was that traditional foe of sailors, scurvy. The ultimate answer is elusive, although a combination of these factors with unusually harsh weather and ice probably fits the bill best.

What scores of searchers failed to find until this decade was the resting places of Erebus and Terror. The video reveals the ships as remarkably well preserved, but they look frail to modern eyes. The silenced bell from Erebus sits in the room, too. More intriguing are objects created from expedition detritus. The local Inuit are thought to have assisted expedition members as they attempted to reach civilization, later repurposing files and tins to make knives, sledge runners and other objects. Their oral history proved decisive in pinpointing the location of the wrecks. Says CMH director-general Jean-Marc Blais: "It was Inuit knowledge that first revealed to searchers where the expedition had become trapped." Local people call an island near where Erebus was found Kivevok, meaning "where it sank", notes Paul Watson in his chronicle of the expedition, Ice Ghosts (W. W. Norton, 2017).

Hopefully, Death in the Ice will rekindle the huge interest in the Arctic that existed in Franklin's day. This compelling region, once so deadly to humans, is now at our mercy as a result of climate change, resource extraction and encroachment. The exhibition is a timely reminder of its environmental and cultural importance, as well as its key place in the human imagination.

Daniel Cressey is a senior reporter for Nature in London. 